\title{
Choroidal metastases from thymic carcinoma during pregnancy: Case Report
}

\author{
Sebastian P. Haen ${ }^{1,2^{*}}$, Philipp Stroebel ${ }^{3,4}$, Alexander Marx ${ }^{3}$, Daniela Suesskind ${ }^{5}$, Falko Fend ${ }^{6}$, Ursula Reichmann ${ }^{7}$, \\ Hans-Georg Kopp ${ }^{1}$, Lothar Kanz ${ }^{1}$ and Frank Mayer ${ }^{1}$
}

\begin{abstract}
Background: Rare sites of metastases, atypical symptoms and paraneoplastic syndromes are often neglected or misinterpreted, especially when they represent early symptoms of an underlying malignant disease. Hence, an interdisciplinary approach to these patients is essential to avoid tumor progression and metastatic spread in order to provide curative treatment options to the patients. We here report the case of a young woman presenting with visual loss which led to diagnosis of a thymic carcinoma.
\end{abstract}

Case presentation: A 28-year old white woman presented with subacute loss of vision in the last trimester of her first pregnancy which was first interpreted as an exacerbation of a pre-existing dermatomyositis and treated with steroids. After failure of steroid therapy choroidal metastases from an undifferentiated thymic carcinoma were diagnosed. This also shed a new light on the dermatomyositis the patient had been suffering from for seven years possibly representing a paraneoplastic syndrome from the tumor. Despite aggressive chemotherapy, the patient died from progressive disease eight years after first onset of dermatomyositis and 14 months after initial diagnosis of the thymic carcinoma.

Conclusions: Choroidal metastases from a thymic carcinoma have never been reported before but should be included into the differential diagnosis of choroidal masses.

Keywords: Thymic carcinoma, Uveal metastasis, Dermatomyositis

\section{Background}

Primary thymic carcinomas are rare tumors accounting for $7-25 \%$ of all neoplasms of the thymus [1]. They are distinguished from the more frequent thymomas based on their different morphology and biology $[2,3]$. Due to frequent invasion of pericardium or pleural space and metastatic spread, their prognosis is generally poor [4] with median survival times for patients with irresectable disease of 13 months [5]. Thymic carcinomas differ from thymomas also with respect to associated paraneoplastic autoimmune diseases. Thymomas are frequently associated with characteristic autoimmune phenomena like myasthenia gravis or pure red cell aplasia, which normally do

\footnotetext{
* Correspondence: sebastian.haen@med.uni-tuebingen.de

${ }^{1}$ Medizinische Universitaetsklinik Tuebingen, Innere Medizin II fuer Onkologie, Haematologie, Immunologie, Rheumatologie und Pulmologie, Otfried Mueller Str. 10, D-72076 Tuebingen, Germany

${ }^{2}$ Interfakultaeres Institut fuer Zellbiologie, Abteilung Immunologie, Auf der Morgenstelle 15, D-72076 Tuebingen, Germany
}

Full list of author information is available at the end of the article not occur in thymic carcinomas. However, sporadic cases of polymyositis or hypercalcemia have been encountered in the latter [6-8].

Choroidal metastases are exceedingly rare. They can occasionally cause symptoms leading to the primary diagnosis of other tumors like lung and breast cancers, as well as melanoma $[9,10]$. However, in most patients the underlying diseases are already diagnosed, and choroidal metastases represent late symptoms of the disease [10].

With the permission of the kin of the patient, we here report a case in which the presentation with visual loss resulted in the diagnosis of a thymic carcinoma which had not been found during earlier examinations.

\section{Case presentation}

A 28-year old white woman presented with distinct deterioration of visual acuity during the last trimester of her first pregnancy. Her vision decreased to 20/40 in the left and 20/400 in the right eye. In the beginning, the visual loss occurred intermittently, but worsened over 
time. In addition, the patient complained about flickering. During the worst episodes she could only see contours with a vague discrimination of light. Simultaneously, symptoms of a dermatomyositis, which had been diagnosed and successfully treated several years earlier, reappeared. At that time, the diagnosis of dermatomyositis had been confirmed by skin biopsy. An extensive workup to rule out an underlying malignancy had then not revealed any suspicious results. However, a CT scan had not been performed. The patient subsequently had received several immunosuppressive treatments including azathioprine, methotrexate and adalimumab, as well as immunoglobulins and steroids resulting in a long-lasting remission of the dermatomyositis.

The decrease in visual acuity occurred isochronal with another exacerbation of skin symptoms and was therefore initially interpreted as a manifestation of the reappearing dermatomyositis and treated with steroids since also initial ophthalmologic workup did not reveal pathological results. After failure of immunosuppressive therapy, repeated ophthalmologic examination revealed an amelanotic choroidal mass at the posterior pole including the peripapillary region and a second choroidal lesion superior to the optic disc in the right eye. Also, in the left eye another amelanotic choroidal tumor situated predominantly nasal superior to the optic disc was detected. In both eyes, an inferior exsudative retinal detachment was seen (Fig. 1a and b). Finally, a large tumor mass in the mediastinum, pleural thickening and pulmonary nodules as well as a mediastinal lymphadenopathy were detected in MRI scans. CT scans were not performed because of the actual pregnancy. After delivery of a healthy boy at the 37th +2 week of pregnancy through Caesarean section, a lung and pleural biopsy was performed by lateral thoracotomy and the patient was referred to our center for further treatment.

The clinical examination showed a 28-year old woman in proper general condition. Her skin was reddish and thickened with distinct flaking. The examination of the heart, lungs and abdomen did not reveal any pathologic results. Decreased visual acuity was noted in both eyes. Additionally, the patient complained about paraesthesia with tickling in both feet. Other neurological symptoms were not detectable.

Laboratory testing revealed a slightly increased creatine kinase (193 U/l, normal up to $170 \mathrm{U} / \mathrm{l})$, an elevated C-reactive protein $(2.77 \mathrm{mg} / \mathrm{dl}$, normal up to $0.5 \mathrm{mg} / \mathrm{dl})$, anemia with haemoglobin of $9.8 \mathrm{~g} / \mathrm{dl}$, elevated uric acid levels of $6.5 \mathrm{mg} / \mathrm{dl}$ (reference range 2.4 to $5.7 \mathrm{mg} / \mathrm{dl}$ ) and a significantly increased lactate dehydrogenase of $959 \mathrm{U} / \mathrm{l}$ (normal up to $250 \mathrm{U} / \mathrm{l}$ ) as well as thrombocytosis of $789 \mathrm{G} / \mu \mathrm{l}$ (normal up to $450 \mathrm{G} / \mu \mathrm{l}$ ).

Whole body CT and MRI scans showed metastases to the choroids, pleura and regional lymph nodes (Fig. 1b and c). The lung biopsy revealed a poorly differentiated carcinoma with strong expression of cytokeratins 5/6, CD5 and CD117 and absence of neuroendocrine markers (CD56; chromogranin, synaptophysin), a constellation highly specific for thymic carcinomas (Fig. 1e and f). A lymphoepithelioma-like thymic carcinoma was ruled out by negative EBV in situ hybridization. In addition, a thymic carcinoma with $\mathrm{t}(15 ; 19)$ translocation was likewise ruled out by specific real-time polymerase chain reaction (RT-PCR), which failed to demonstrate a BRD4-NUT gene fusion product. Thus a final diagnosis of an undifferentiated thymic carcinoma was established. The tumor at initial diagnosis presented in stage IVb (T4, N2 (hilar lymph nodes), M1b (pleura, lung, choroid)) [11, 12].

Thymic carcinomas are often moderately differentiated squamous cell carcinomas histologically resembling the appearance of squamous cell carcinomas elsewhere in the body, e.g. the lung $[13,14]$. In our patient, one potential differential diagnosis was the lymphocyte poor EBV-associated lymphoepithelioma-like carcinoma, an aggressive tumor with a poor prognosis $[15,16]$. However, EBV association was ruled out by in situ hybridisation. Another differential diagnosis in young adults with a rapidly progressive carcinoma is the so-called thymic carcinoma with $t(15 ; 19)$ translocation, which is associated with a fatal prognosis, including rapid local invasion and systemic dissemination [17-20]. In our case, this diagnosis could also be ruled out, since the BRD4-NUT fusion gene transcript resulting from this chromosomal translocation could not be detected. Hence, a final diagnosis of a high grade, poorly differentiated thymic carcinoma was established by exclusion of other possible subtypes of primary thymic carcinomas.

Classical metastatic spread patterns of thymic carcinoma comprise regional anterior perithymic, deep intrathoracic and cervical lymph nodes, as well as the pleura, the pericardium and the lung [12]. Extrathoracic organ metastases mainly affect the liver and the kidney, but may also involve the bones [4, 21-24]. Also one case of orbit metastases from a neuroendocrine thymic carcinoma was reported [25].

To our knowledge, our patient represents the first case of choroidal metastases from thymic carcinoma. Although choroidal metastases are generally rare (e.g. about $5-10 \%$ in breast and lung carcinoma patients, respectively [26, 27]), the choroid represents the most common ocular site for metastatic disease (up to $88 \%$ of secondary ocular tumors) which is due to hematogenenous dissemination into abundant choroidal vasculature $[9,28,29]$. The most common primary tumors presenting with choroidal metastases are breast (40$53 \%)[9,26,30-32]$ and lung carcinoma (20-29 \%) $[9,30,33]$ but may also include tumors $(2-4 \%$ each) from the gastrointestinal tract, the kidney, the prostate 


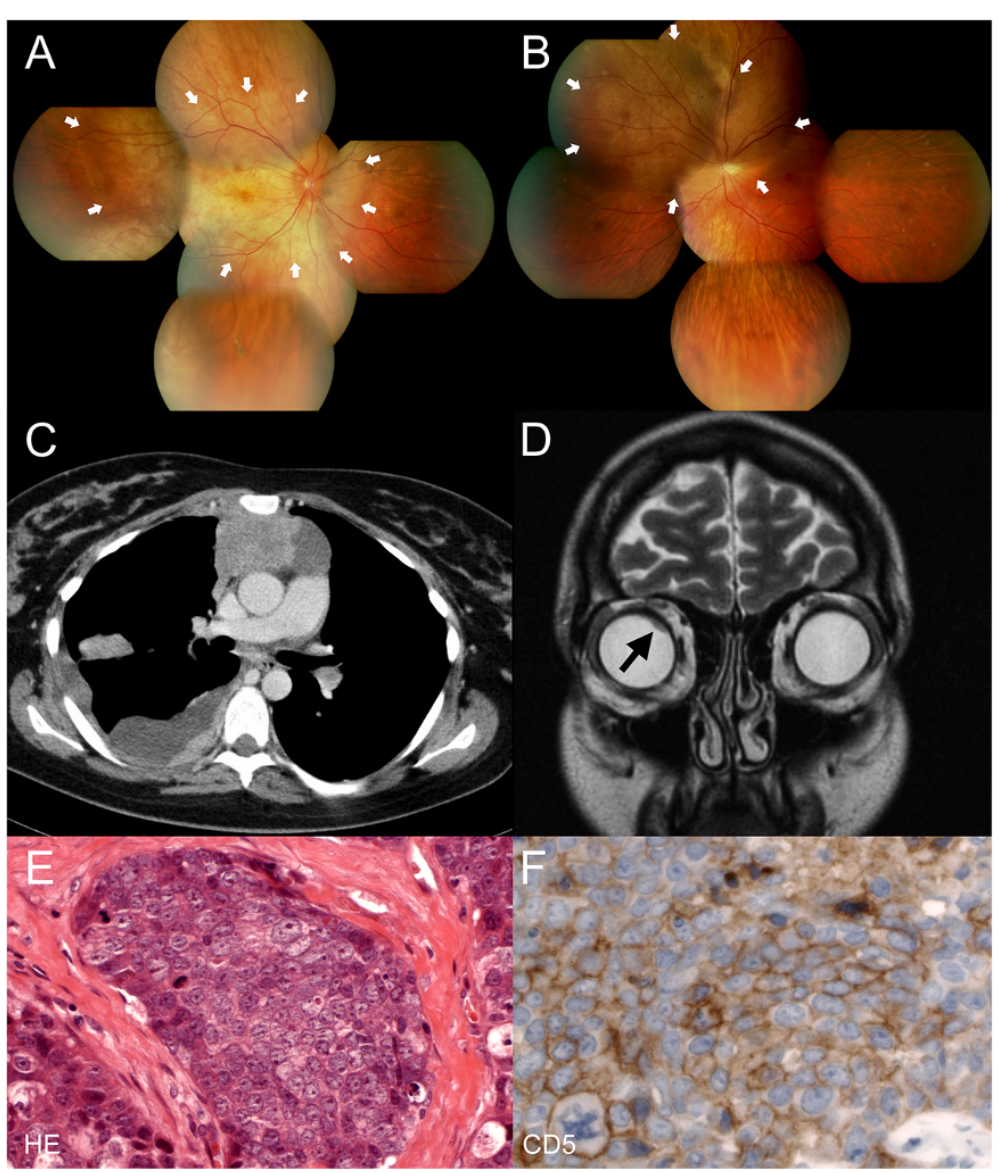

Fig. 1 Diagnostic evaluation. a and $\mathbf{b}$ Composite color fundus photographs of both eyes showing the amelanotic choroidal lesions (arrows) at the posterior pole of the right eye (a) and predominantly nasal superior to the optic disc in the left eye (b). $\mathbf{c}$ and $\mathbf{d}$ Radiographic imaging. CT scan of the chest (c). Note the large mediastinal mass with pleural spreading. MRI scan of the orbits (d). The arrow marks the choroidal lesion. $\mathbf{e}$ and $\mathbf{f}$ Histological appearance of the undifferentiated thymic carcinoma (400-fold magnification). The H\&E stain (e) shows compact nests of undifferentiated epithelial cells with narrow cytoplasm without evidence of keratinization, large vesicular nuclei and high mitotic rate, separated by broad collagen bands (immunostaining for CD5). The tumor cells show a strong expression of CD5 (f) characteristic for an undifferentiated thymic carcinoma

and the skin [9, 30, 34-39], as well as carcinoid tumors of different localisation including one reported case of a thymic carcinoid [40]. Evidence for choroidal metastases from other tumors has emerged in recents years. These observations are mainly limited to single case reports and comprise metastases from malignancies of the thyroid [29, 41-45], the urogenital tract [46-49], the pancreas [50, 51], salivary glands [52, 53], and the chorion [54], as well as sarcomas [55, 56].

In our patient, fractioned radiation therapy of the orbits with a cumulative dose of 30 Gy $(10 \times 3$ Gy $)$ using opposite, coplanar and coaxial fields in an isocentric adjustment with $6 \mathrm{MV}$ photons was performed and resulted in regression of the choroidal metastases and an improvement of visual acuity from $20 / 400$ to $20 / 40$ in the right eye and from $20 / 40$ to $20 / 16$ in the left eye resulting in reconstitution of reading ability. Afterwards, chemotherapy with Cisplatin $\left(75 \mathrm{mg} / \mathrm{m}^{2}\right)$ and Paclitaxel $\left(175 \mathrm{mg} / \mathrm{m}^{2}\right)$ was initiated as a $\mathrm{t}(15 ; 19)$-positive carcinoma was still assumed at that time. Due to the rapid clinical response, this treatment was continued for a total of six cycles after receiving the final pathology report. After four cycles, a good partial response was observed in CT scan. However, progressive disease was evident in the staging after six cycles. The regime was then changed to a modified PAC-scheme (Carboplatin AUC5 instead of cisplatin because of a suspected paclitaxel-induced peripheral polyneuropathy CTC grade 1, Doxorubicin $50 \mathrm{mg} / \mathrm{m}^{2}$ and Cyclophosphamide $500 \mathrm{mg} / \mathrm{m}^{2}$ ). Nevertheless, the tumor progressed further, and the patient died of progressive disease in respiratory insufficiency eight years after first manifestation of the dermatomyositis and fourteen months after primary diagnosis. The median overall survival of patients with undifferentiated thymic carcinoma has been reported to be about six months [57]. 
Retrospectively, the pre-existing dermatomyositis might have represented the first symptom of an at that time clinically occult tumor. The association between the epithelial thymic carcinoma and the dermatomyositis in this case could not be totally proven but such an association has been reported in some cases of thymomas [58], but appears to be extremely rare in thymic carcinomas with only two reports in the literature [59,60].

\section{Conclusions}

Our case demonstrates that thymic carcinomas should be included into the differential diagnosis in cases with choroidal metastases and with dermatomyositis and no detectable tumor, especially in young adults. To our knowledge, this is the first case of a thymic carcinoma with highly aggressive and fatal course and atypical clinical presentation with choroidal metastases.

\section{Consent}

Written informed consent was obtained from the patient's relatives for publication of this case report and the accompanying images. A copy of the written informed consent is available for review by the Editor-in-Chief upon request.

\begin{abstract}
Abbreviations
BRD: bromodomain-containing protein; CD: cluster of differentiation; CT: computed tomography; EBV: epstein barr virus; HE: hematoxylin eosin; MRI: magnetic resonance imaging; MV: megavolt; NUT: nuclear protein in testis; PAC: platinum adriamycin cyclophosphamide; RT-PCR: real-time polymerase chain reaction.
\end{abstract}

\section{Competing interests}

The authors declare that they have no competing interests to disclose.

\section{Authors' contributions}

SPH: Acquisition of data, analysis and interpretation of data, corresponding author, drafting and critical revision of the article. PS: Acquisition of data, analysis and interpretation of data, critical revision of the article. AM: Acquisition of data, analysis and interpretation of data, critical revision of the article. DS: Acquisition of data, analysis and interpretation of data, critical revision of the article. FF: Acquisition of data, analysis and interpretation of data, critical revision of the article. UR: Acquisition of data, analysis and interpretation of data, critical revision of the article. HGK: Acquisition of data, analysis and interpretation of data, critical revision of the article. LK: Acquisition of data, analysis and interpretation of data, supervision of the study, critical revision of the article. FM: Conception and design, acquisition of data, analysis and interpretation of data, supervision of the study, critical revision of the article. All authors read and approved the submitted version of the article.

\section{Acknowledgements}

Sebastian P. Haen is supported by the Deutsche José Carreras Leukemia Foundation (Grant-No. DJS 08/04). The authors wish to thank Lynne Yakes for editorial assistance.

\section{Funding}

Sebastian P. Haen was supported by the Deutsche José Carreras Leukemia Foundation (Grant-No. DJS 08/04).

\section{Author details}

${ }^{1}$ Medizinische Universitaetsklinik Tuebingen, Innere Medizin II fuer Onkologie, Haematologie, Immunologie, Rheumatologie und Pulmologie, Otfried Mueller Str. 10, D-72076 Tuebingen, Germany. Interfakultaeres Institut fuer Zellbiologie, Abteilung Immunologie, Auf der Morgenstelle 15, D-72076
Tuebingen, Germany. ${ }^{3}$ Pathologisches Institut, Universitaetsmedizin Mannheim, Theodor-Kutzer-Ufer 1-3, D-68167 Mannheim, Germany. ${ }^{4}$ Institut fuer Pathologie, Universitaetsmedizin Goettingen, Robert-Koch-Str. 40, D-37075 Goettingen, Germany. ${ }^{5}$ Departement fuer Augenheilkunde, Universitaetsklinikum Tuebingen, Schleichstr. 12, D-72076 Tuebingen, Germany. ${ }^{6}$ Institut fuer Pathologie, Abteilung fuer Allgemeine Pathologie und Pathologische Anatomie, Universitaetsklinikum Tuebingen, Liebermeisterstr. 8, D-72076 Tuebingen, Germany. ${ }^{7}$ Radioonkologische Klinik,

Universitaetsklinikum Tuebingen, Hoppe-Seyler-Str. 3, D-72076 Tuebingen, Germany.

Received: 20 April 2015 Accepted: 1 December 2015

Published online: 16 December 2015

\section{References}

1. Muller-Hermelink HK, Engel P, Kuo TT, Strobel P, Marx A, Harris NL, et al. Tumours of the thymus. Introduction. 2004;3rd:145-51.

2. Pan CC, Chen PC, Chiang H. Kit (CD117) is frequently overexpressed in thymic carcinomas but is absent in thymomas. J Pathol. 2004;202:375-81.

3. Strobel P, Knop S, Einsele H, Muller-Hermelink HK, Marx A. Therapy-relevant mutations of receptor tyrosine kinases in malignant thymomas and thymic carcinomas: a therapeutic perspective. Verh Dtsch Ges Pathol. 2007;91:177-86.

4. Suster S, Rosai J. Thymic carcinoma. A clinicopathologic study of 60 cases. Cancer. 1991;67:1025-32.

5. Takeda S, Sawabata N, Inoue M, Koma M, Maeda H, Hirano H. Thymic carcinoma. Clinical institutional experience with 15 patients. Eur J Cardiothorac Surg. 2004;26:401-6.

6. Yoshiike F, Koizumi T, Yoneyama A, Komatu M, Yamaguchi S, Hanaoka M, et al. Thymic squamous cell carcinoma producing parathyroid hormonerelated protein and CYFRA 21-1. Intern Med. 2004;43:493-5.

7. Inoue Y, True LD, Martins RG. Thymic carcinoma associated with paraneoplastic polymyositis. J Clin Oncol. 2009;e33:4. doi:10.1200/JCO.2009.22.1176.

8. Jordan B, Eger K, Zierz S. [Polymyositis associated with thymoma.]. Nervenarzt. 2009;708-11; doi:10.1007/s00115-009-2689-1.

9. Shields CL, Shields JA, Gross NE, Schwartz GP, Lally SE. Survey of 520 eyes with uveal metastases. Ophthalmology. 1997;104:1265-76.

10. Arepalli S, Kaliki S, Shields CL. Choroidal metastases: origin, features, and therapy. Indian J Ophthalmol. 2015;63:122-7. doi:10.4103/0301-4738.154380.

11. Koga $K$, Matsuno $Y$, Noguchi M, Mukai $K$, Asamura H, Goya T, et al. A review of 79 thymomas: modification of staging system and reappraisal of conventional division into invasive and non-invasive thymoma. Pathol Int. 1994:44:359-67.

12. Bhora FY, Chen DJ, Detterbeck FC, Asamura H, Falkson C, Filosso PL, et al. The ITMIG/IASLC thymic epithelial tumors staging project: a proposed lymph node map for thymic epithelial tumors in the forthcoming 8th edition of the TNM classification of malignant tumors. J Thorac Oncol. 2014; 9:S88-96. doi:10.1097/JTO.0000000000000293.

13. Kuo $T$, Chan JK. Thymic carcinoma arising in thymoma is associated with alterations in immunohistochemical profile. Am J Surg Pathol. 1998;22:1474-81.

14. Suster S, Moran CA. Primary thymic epithelial neoplasms showing combined features of thymoma and thymic carcinoma. a clinicopathologic study of 22 cases. Am J Surg Pathol. 1996;20:1469-80.

15. Dimery IW, Lee JS, Blick M, Pearson G, Spitzer G, Hong WK. Association of the Epstein-Barr virus with lymphoepithelioma of the thymus. Cancer. 1988; 61:2475-80.

16. Leyvraz S, Henle W, Chahinian AP, Perlmann C, Klein G, Gordon RE, et al. Association of Epstein-Barr virus with thymic carcinoma. N Engl J Med. 1985; 312:1296-9.

17. Kubonishi I, Takehara N, Iwata J, Sonobe H, Ohtsuki Y, Abe T, et al. Novel t $(15 ; 19)(q 15 ; p 13)$ chromosome abnormality in a thymic carcinoma. Cancer Res. 1991;51:3327-8.

18. Lee AC, Kwong YI, Fu KH, Chan GC, Ma L, Lau YL. Disseminated mediastinal carcinoma with chromosomal translocation (15;19). A distinctive clinicopathologic syndrome. Cancer. 1993;72:2273-6.

19. Toretsky JA, Jenson J, Sun CC, Eskenazi AE, Campbell A, Hunger SP, et al. Translocation (11;15;19): a highly specific chromosome rearrangement associated with poorly differentiated thymic carcinoma in young patients. Am J Clin Oncol. 2003;26:300-6.

20. Petrini P, French CA, Rajan A, Cameron MJ, Jaffe ES, Zucali PA, et al. NUT rearrangement is uncommon in human thymic epithelial tumors. J Thorac Oncol. 2012;7:744-50. doi:10.1097/JTO.0b013e3182460f8f. 
21. Hsu CP, Chen CY, Chen CL, Lin CT, Hsu NY, Wang JH, et al. Thymic carcinoma. ten years experience in twenty patients. J Thorac Cardiovasc Surg. 1994;107:615-20.

22. Moran CA, Suster S. Thymic carcinoma: current concepts and histologic features. Hematol Oncol Clin North Am. 2008;22:393-407. doi:10.1016/j.hoc 2008.03.002.

23. Liu T, Qiu G, Tian Y. Thymic carcinoma with primary spine metastasis. J Clin Neurosci. 2011;18:840-2. doi:10.1016/j.jocn.2010.08.038.

24. Sasaki S, Fukushima T, Maruyama Y, Gomi D, Kobayashi T, Sekiguchi N, et al. Two cases of thymic carcinoma initially presenting as bone metastasis: a clinical report and the usefulness of CD5 immunohistochemistry for assessing bone lesions. Intern Med. 2015;54:1781-5. doi:10.2169/ internalmedicine.54.4250.

25. MacLean KD, Cole SC, Ford JR, Owen L, Mamalis N, Patel BC. Thymic origin neuroendocrine carcinoma metastasizing to the orbit in an otherwise asymptomatic patient. Ophthal Plast Reconstr Surg. 2015;41(5):1081-7.

26. Wiegel T, Kreusel KM, Bornfeld N, Bottke D, Stange M, Foerster MH, et al. Frequency of asymptomatic choroidal metastasis in patients with disseminated breast cancer: results of a prospective screening programme. Br J Ophthalmol. 1998;82:1159-61.

27. Kreusel KM, Wiegel T, Stange M, Bornfeld N, Hinkelbein W, Foerster MH. Choroidal metastasis in disseminated lung cancer: frequency and risk factors. Am J Ophthalmol. 2002;134:445-7.

28. Eliassi-Rad B, Albert DM, Green WR. Frequency of ocular metastases in patients dying of cancer in eye bank populations. Br J Ophthalmol. 1996;80:125-8.

29. Avram AM, Gielczyk R, Su L, Vine AK, Sisson JC. Choroidal and skin metastases from papillary thyroid cancer: case and a review of the literature. J Clin Endocrinol Metab. 2004;89:5303-7.

30. Ferry AP, Font RL. Carcinoma metastatic to the eye and orbit. I. A clinicopathologic study of 227 cases. Arch Ophthalmol. 1974;92:276-86.

31. Merrill CF, Kaufman DI, Dimitrov NV. Breast cancer metastatic to the eye is a common entity. Cancer. 1991;68:623-7.

32. Demirci H, Shields CL, Chao AN, Shields JA. Uveal metastasis from breast cancer in 264 patients. Am J Ophthalmol. 2003;136:264-71.

33. Shah SU, Mashayekhi A, Shields CL, Walia HS, Hubbard III GB, Zhang J, et al. Uveal metastasis from lung cancer: clinical features, treatment, and outcome in 194 patients. Ophthalmology. 2014;121:352-7. doi:10.1016/j. ophtha.2013.07.014.

34. Fernandez-Perez S, Ruiz-Moreno O, Pueyo V, La De MG, Pablo L. Bilateral choroidal metastases as presentation of dissemination of cutaneous malignant melanoma. Case Rep Ophthalmol Med. 2012;2012:486167. doi:10.1155/2012/ 486167.

35. Kawai S, Nishida T, Hayashi Y, Ezaki H, Yamada T, Shinzaki S, et al. Choroidal and cutaneous metastasis from gastric adenocarcinoma. World J Gastroenterol. 2013;19:1485-8. doi:10.3748/wjg.v19.i9.1485.

36. Tei $M$, Wakasugi $M$, Akamatsu $H$. Choroidal metastasis from early rectal cancer: case report and literature review. Int J Surg Case Rep. 2014;5:1278-81. doi:10.1016/j.jjscr.2014.10.059.

37. Grajewski RS, Schuler-Thurner B, Mauch C, Kreuzberg N, Koch KR, Bergua A et al. Ocular diseases in metastatic cutaneous melanoma: review of 108 consecutive patients in two german tertiary centers. Graefes Arch Clin Exp Ophthalmol. 2014;252:679-85. doi:10.1007/s00417-013-2563-5.

38. Ngo E, Hutchins LF, Gardner JM, Uwaydat SH. Regression of orbital and choroidal metastases from melanoma after treatment with vemurafenib. Can J Ophthalmol. 2014;49:e49-52. doi:10.1016/j.jcjo.2013.12.012.

39. Maudgil A, Sears KS, Rundle PA, Rennie IG, Salvi SM. Failure of intravitreal bevacizumab in the treatment of choroidal metastasis. Eye (Lond). 2015;29: 707-11. doi:10.1038/eye.2015.21.

40. Harbour JW, De PP, Shields CL, Shields JA. Uveal metastasis from carcinoid tumor. clinical observations in nine cases. Ophthalmology. 1994;101:1084-90.

41. Kiratli H, Tarlan B, Soylemezoglu F. Papillary thyroid carcinoma: bilateral choroidal metastases with extrascleral extension. Korean J Ophthalmol. 2013;27:215-8. doi:10.3341/kjo.2013.27.3.215.

42. Besic N, Luznik Z. Choroidal and orbital metastases from thyroid cancer. Thyroid. 2013;23:543-51. doi:10.1089/thy.2012.0021.

43. Papastefanou VP, Arora AK, Hungerford JL, Cohen VM. Choroidal metastasis from follicular cell thyroid carcinoma masquerading as circumscribed choroidal haemangioma. Case Rep Oncol Med. 2014;2014:251817. doi:10.1155/2014/251817

44. Patil D, Kumaraswamy KA, Kodaganur GS, Swamy S, Shankarappa A, Kodaganur SG. lodophilic synchronous phalangeal and choroidal metastasis from follicular thyroid carcinoma: a case report and review. Eur Thyroid J. 2014;3:134-6. doi:10.1159/000360533.

45. Makhija C, Su YB, Goldner W. Unusual case of papillary thyroid carcinoma with choroidal metastasis. Thyroid. 2015;25:860-4. doi:10.1089/thy.2014.0511.

46. De Potter P, Shields CL, Shields JA, Tardio DJ. Uveal metastasis from prostate carcinoma. Cancer. 1993;71:2791-6.

47. Nabi G, Dadeya S, Dogra PN, Lal H. Eye metastasis form urothelial tumours. Int Urol Nephrol. 2002;34:51-4.

48. Singh DV, Gupta V, Singh SK. Choroid metastasis from testicular carcinoma: a rare entity. Urol Int. 2013.

49. Mitsui $Y$, Arichi N, Inoue K, Hiraki M, Nakamura S, Hiraoka T, et al. Choroidal and cutaneous metastasis from urothelial carcinoma of the bladder after radical cystectomy: a case report and literature review. Case Rep Urol. 2014; 2014:491541. doi:10.1155/2014/491541

50. Yiu G, Cummings TJ, Mruthyunjaya P. Choroidal metastatasis from a neuroendocrine tumor masquerading as choroidal melanoma. Ophthalmic Surg Lasers Imaging Retina. 2014;45:456-8. doi:10.3928/23258160-20140725-01.

51. Bilgin AB, Apaydin KC, Unal M, Ilhan HD, Turkoglu EB, Aydin N. A case report of bilateral choroidal metastases of epithelial carcinoma of pancreas. Arq Bras Oftalmol. 2014;77:259-60.

52. Shields JA, Carvalho C, Shields CL, Singh AD, Wagner D. Bilateral choroidal metastasis from adenoid cystic carcinoma of the submandibular gland. Retina. 2000;20:406-7.

53. Walls G, Napier S, Stewart D. Visual impairment due to bilateral multifocal choroidal metastasis of parotid adenocarcinoma: a case report. Front Oncol. 2014;4:136. doi:10.3389/fonc.2014.00136.

54. Hazan A, Katz MS, Leder H, Blace N, Szlechter M. Choroidal metastases of choriocarcinoma. Retin Cases Brief Rep. 2014:8:95-6. doi:10.1097/ICB. 0000000000000012.

55. Krema H, McGowan $H$, Tanzer $H$, Simpson $R$, Laperriere N. Unusual orangecolored choroidal metastases. J Ophthalmic Vis Res. 2013;8:53-7.

56. Cristina NG, Francisco ED, Vanesa RG, Fernando CG, Luis CM, Emiliano HG. Choroidal metastasis from primary bone leiomyosarcoma. Int Ophthalmol. 2015;35:721-5. doi:10.1007/s10792-015-0096-0.

57. Lin JT, Wei-Shu W, Yen CC, Liu JH, Chen PM, Chiou TJ. Stage IV thymic carcinoma: a study of 20 patients. Am J Med Sci. 2005;330:172-5.

58. Ago T, Nakamura M, Iwata I, Murai H, Okuma K, Tsuru T, et al. Dermatomyositis associated with invasive thymoma. Intern Med. 1999;38: 155-9.

59. Fong PH, Wee A, Chan HL, Tan YO. Primary thymic carcinoma and its association with dermatomyositis and pure red cell aplasia. Int J Dermatol. 1992;31:426-8.

60. Takahashi F, Tsuta K, Nagaoka T, Miyamoto H, Saito Y, Amano H, et al. Successful resection of dermatomyositis associated with thymic carcinoma: report of a case. Surg Today. 2008;38:245-8. doi:10.1007/s00595-007-3601-x.

\section{Submit your next manuscript to BioMed Central and we will help you at every step:}

- We accept pre-submission inquiries

- Our selector tool helps you to find the most relevant journal

- We provide round the clock customer support

- Convenient online submission

- Thorough peer review

- Inclusion in PubMed and all major indexing services

- Maximum visibility for your research

Submit your manuscript at www.biomedcentral.com/submit 